\title{
Nature and Causes of Inter-Ethnic Conflicts in Nyakach and Sigowet Sub-Counties of Western Kenya
}

\author{
James Omondi Juma, Ruth Simiyu \\ Department of Peace and Conflict Studies, Masinde Muliro University of Science and Technology, Kakamega, Kenya \\ Email: jamesjomondi1@gmail.com,rsimiyu@mmust.ac.ke
}

How to cite this paper: Juma, J.O. and Simiyu, R. (2019) Nature and Causes of Inter-Ethnic Conflicts in Nyakach and Sigowet Sub-Counties of Western Kenya. Open Journal of Social Sciences, 7, 453-477. https://doi.org/10.4236/jss.2019.77037

Received: June 11, 2019

Accepted: July 28, 2019

Published: July 31, 2019

Copyright (อ 2019 by author(s) and Scientific Research Publishing Inc. This work is licensed under the Creative Commons Attribution International License (CC BY 4.0).

http://creativecommons.org/licenses/by/4.0/

\section{(c) (i) Open Access}

\begin{abstract}
The causes of inter-ethnic conflict are complex as they are deeply rooted into the socio-cultural beliefs of the society. This study was guided by the Primordialism theory. The study employed descriptive research design. The study utilized both primary and secondary data. Data collection was done using questionnaires, interviews and Focus Group Discussions. Data were analyzed using the Statistical Packages for Social Scientists (SPSS 17). Data were presented in tables, bar graphs and pie charts. The findings of the study revealed that the conflicts in Nyakach and Sigowet Sub-counties were attributed to cattle rustling, political incitement and retaliatory attacks with the key perpetrators of the conflicts being politicians, youths and cattle rustlers. The conflicts were recurrent and largely affected the communities. Additionally, the recurrent conflicts were largely witnessed along the borders of the two sub-counties. The study concluded that both socio-cultural factors and politics had a lot of bearing on conflicts and as such members of the community and political players were key stakeholders if the conflicts were to be averted in the long term.
\end{abstract}

\section{Keywords}

Inter-Ethnic Conflicts, Sporadic Violence, Ethnic Groups, Types of Conflicts, Cattle Raiding

\section{Introduction}

Ethnic conflicts are based on socio-cultural issues which entail meanings, values, norms, status, and classes in a society which are the common components for potential conflict and, indeed, the components of socio-cultural space in a con- 
flict situation. The underlying causes of inter-ethnic conflict are thus complex as they are deeply rooted into the socio-cultural beliefs of the society [1]. Scholars of ethnic conflicts and civil wars argue that certain types of disputes are difficult to reconcile thus leading to the repetition of confrontations [2]. Conflicts between competing ethnic groups mainly border on identity and are thus believed to be intractable. Moreover, once conflicts break out, ethnic identities and hatred tend to become cemented in ways that make cooperation and coexistence between the groups even more difficult, and these are the conflicts that are likely to recur over time.

The recurring conflict in the Balkans, as well as the repeated violence between groups such as the Hutus and Tutsis, Turks and Armenians, Jews and Arabs, is often identified as examples of these conflicts where ethnic perceptions have played a big role in the recurrence [2]. The presence and persistence of socio-cultural biases and discriminatory attitudes and practices can be readily identified as major contributors towards recurrence of ethnic conflicts since these biases leave the disenfranchised ethnic groups vulnerable and are ready to fight for their own identity recognition [3]. During the Kosovo crisis for instance, following the Serb maltreatment of the Albanians, the Ethnic Albanians resorted to violence as a way of expressing their anger towards the Mistreatment by the Slobodan Milosevic led Serb regime; they demanded an independent Kosovo. This resulted in a bloody ethnic conflict marred by killings, rape, and ethnic cleansing [4].

Bias and discrimination can take various forms including acts such as social exclusion. Bias and discrimination may be aimed at preventing a particular group or groups from fully participating in and benefiting from the wealth, power, knowledge and decision-making capacities of the larger society. At their worst, socio-economic biases and discrimination can produce feelings of disempowerment, hopelessness and despair for the future, further exacerbating vulnerability and hatred among the excluded groups [5]. For instance, Milosevic's regime acted to exclude Albanians from education, banned the official use of Albanian language, severely restricted the use of Albanian symbols and attempted to redress the demographic imbalance between the Serbs and Albanians [4]. As Lake \& Rothchild (2001) quoted in [4] argue, ethnic conflicts result from the collective fear of the future (often lived through the shared memories of the past) by groups that feel unprotected by the state. Thus, Albanians rather than getting protection faced persecution by the state, insecurity increased ethnic $\mathrm{Al}$ banian solidarity hence deepening the mutual hatred against the Serbs. Similarly, group perceptions and historical memories are said to account for the Hutu slaughter of Tutsis in Rwanda, which Hutus regard as self-defences not genocide [6].

In Rwanda, before the 1994 Tutsi genocide, the media was used to spread hate messages against the Tutsi and this played even a bigger role to fuel the inter-ethnic conflicts in Rwanda that claimed lives of more than 800,000 people [7] 
For instance, Radio Television Libre des Mille Collines (RTLM) opposed peace talks between President Habyarimana and the Tutsi-led rebels of the Rwandan Patriotic Front (RPF), which formed the government. After the downing of the President's plane, RTLM called for "final war" to "exterminate the cockroaches." During the war that followed RTLM broadcasted list of names of people to be killed and where to find them. This made the genocide worse as the Media house was seen as giving specific instructions to killers on who to kill and where to find them [7].

The use of hate speech has never been any different, and Kenya has not been an exception and is a major driver of inter-ethnic violence. Leaders have often used the media, rallies and other platforms to peddle hate messages aimed at in sighting communities against one another. During the first wave of violence in Kenya, between 1991-1994, "KANU politicians instilled fear among the KAMATUSA ethnic groups, alleging that Kikuyu settlers would expropriate their land in case the Kikuyu won the elections; regarding the opposition as a threat, the leaders called upon the ethnic groups to remain united against their common threat." [8]. During, the rallies, Kalenjin politicians threatened to drive away non-Kalenjin communities for failure to their support for KANU [9]. They referred to the non KANU supporters as "Madoadoa" or stains which needed to be removed for their land [10]. The supporters of KANU threatened to chop off the fingers of those who were seen flashing the two finger salute which was a sign used by opposition as opposed to the one finger salute by the ruling party [11]. Inter-ethnic conflicts therefore emerge from a myriad of factors which can be deep rooted and long lasting between various communities. These conflicts take different forms and can be caused and perpetuated by diffident socio-cultural, economic and political factors which the study sought to unearth in the context of Nyakach and Sigowet Sub-counties based on the cases of sporadic violence that have been experienced in the area over the last two decades.

\section{Theoretical Framework}

This study was guided by the Primordialism theory. The main proponent of this theory is Clifford Geertz [12]. Another scholar who has given meaning to the theory is Tatu Vanhanen [13]. According to the primordialism theory, primordial groups such as ethnicities, clans or racial groups are major actors in a polity within which culture, economy and social life is organised. In this regard ethnic identity for instance is given at birth and is passed through genealogy from one generation to another. Therefore under primordialism ethnicity as an identity is fixed through the shared blood relations. In this regard, primordialism envisions cordial and cooperative relationship among members of an ethnic group (in-group) and hostile and conflictual relations with members of an out-group (another ethnic group). Therefore it is in primordialists belief that ethnic conflict essentially spirals from differences in ethnic identities. By putting emphasis 
on the differences in ethnic identities as the foundational basis of inter-ethnic hatreds, fear, and conflicts, primordialists suggest that, ethnically heterogeneous societies will unavoidably experience ethnic conflicts [13]. The theory further argues that apart from identity issues, Inter-ethnic conflicts can result from social and political changes or identity crisis propelled by political or historical transformation of the society. The societal dynamic in Nyakach and Sigwet sub-counties are based on the differences in ethnicities and cultures between the Luo and Kipsigis communities who are inhabitants of the two sub-counties which can explain the reasons for the recurrent conflicts in the area. The primordialism theory in this regard helped the researcher put into perspective the dynamics of the two communities and how these dynamics made it difficult for various factors including local community members to find lasting a solution to the conflict hence the recurrence of conflicts experienced in the region.

\section{Methodology}

\subsection{Research Design}

The researcher employed descriptive research design. Descriptive research design as a method of collecting information by interviewing or administering a questionnaire to a sample of individuals [14]. Descriptive survey can be used to collect information about people's attitude, opinions, habits or social issues [15]. This study evaluated the social context of the recurrence inter-ethnic conflicts in Nyakach and Sigowet Sub-counties of Western region, Kenya. Descriptive survey was employed because it allowed the researchers to adopt a holistic approach in the study, thus enabling and utilizing research tools like questionnaires, interviews and focused group discussion guides.

\subsection{Study Area}

The research was conducted in Sigowet sub-county of Kericho County and Nyakach Sub County of Kisumu County. According to Kenya National Bureau of Statistics, Nyakach sub-county has a population of 133,041 and a total area of 357.30 Square kilometres and Sigowet sub-county on the other hand has a population of 105,124 and an area of 473.10 Square kilometres [16]. The climate here has made it possible for the locals to practice a number of economic activities such as tea farming and dairy farming. Sigowet sub-county has a wonderful climate and is an agriculturally rich area known for its green tea leaves, other common cash crops grown in this sub county are sugar cane and maize. Nyakach Sub-county on the other hand was a number of economic activities in including small scale crop farming, fishing, and sand harvesting. The two sub counties however share certain economic activities such as livestock keeping and trading. Sondu market situated at the border of the two sub-county is shared and is a very important trading centre in the area. Sondu Market attracts people from other counties including Homabay, Nyamira and Kisii counties. The proximity of central positioning of Sondu market has made inter-communal trade to flou- 
rish in the area bringing together three different ethnic communities, namely the Luo, Kisii and the Kipsigis. The Sondu is at the border with a section of the market in Nyakach Sub-county and the other half in Sigowet Sub-county. Population explosion has also seen the area face land issues with people from Nyakach looking for land to settle on the Sigwet side and vice versa. The Sondu market area is often a buzz with business activities until ethnic conflicts erupt. It is one of the areas at the border the normally faces the greatest levels of violence during conflicts. Map of the study area is shown in Figure 1.

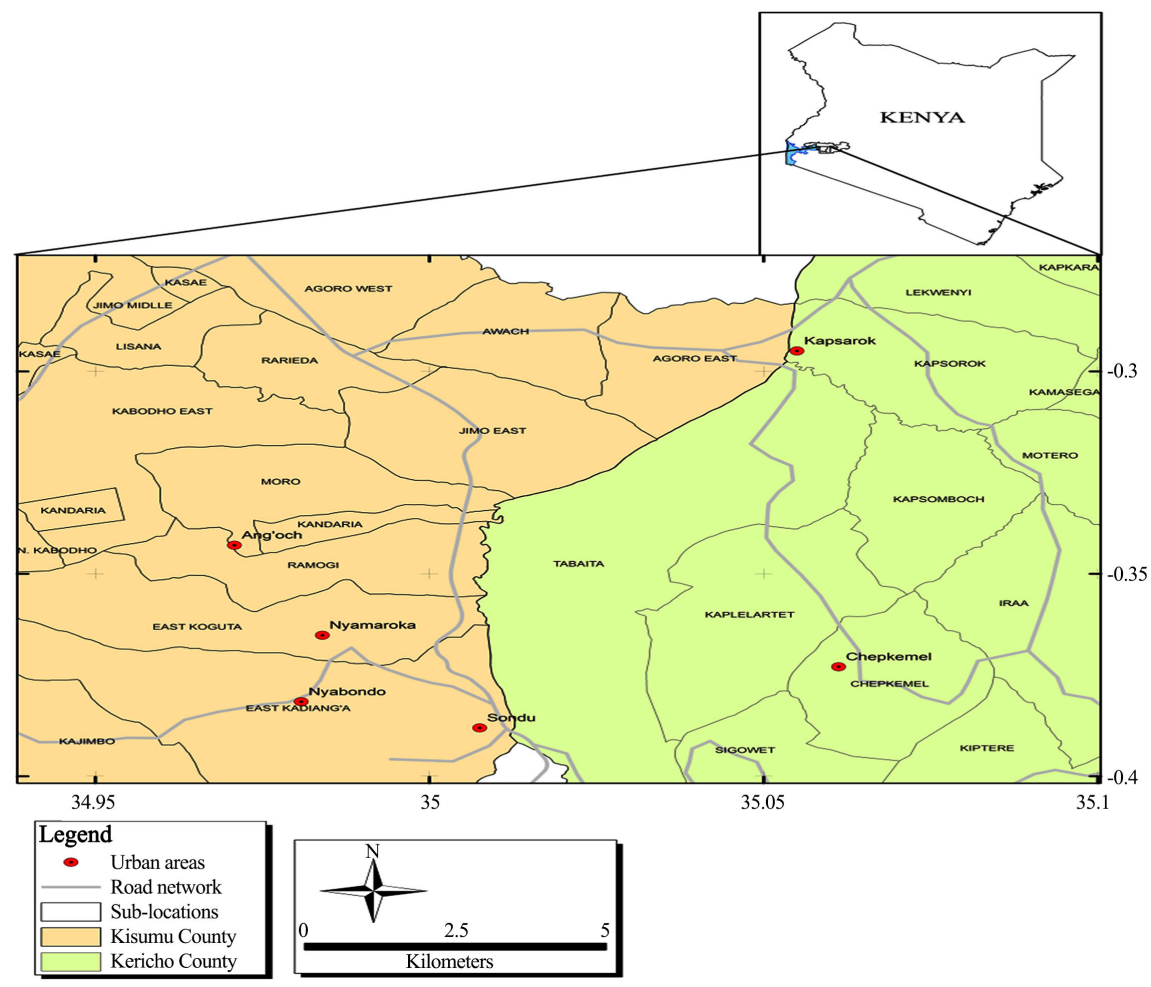

Figure 1. Map of Nyakach and Sigowet Sub-Counties. Source: Author, 2017.

\subsection{Study Population}

The study population comprised of the following categories of respondents within the two sub-counties: household heads, Government officials: Members of county assembly; Sub-county administrators; chiefs, police officers (Administration Police and Anti-Stock Theft Unit); Community members who included: District Peace Committee of Peace committee; elders; women; youths; and Civil Society Organizations including NGOs, CBOs and FBOs also formed part of the target population.

\subsection{Sampling Strategy}

The study employed both probability and non-probability sampling techniques. The sample size was determined using Fisher's formula for sample size determination. Fisher's, sampling formula cited in [15]. As follows 


$$
n=\frac{z^{2} p q}{d^{2}}
$$

where $n=$ desired sample size (the target population is greater than 10,000);

$Z=$ the standard normal deviate at the confidence level of $95 \%$ is 1.96 ;

$p=$ the proportion of the target population estimated to have characteristics being measured is set at $50 \%$;

$q=1-p$ (probability of non-success);

$d=$ level of statistical significance set at 0.05 .

$$
n=\frac{(1.96)^{2} \times 0.5 \times(1-0.5)}{(0.05)^{2}}
$$

$n=384$.

The sample population of 384 respondents was distributed as follows; 38 government officials, 10 Non-state actors and 40 respondents in four FGDs (10 respondents per FGD) and 296 household respondents distributed as indicated in Table 1.

\subsection{Data Collection and Analysis}

Primary data collection was done through the use of questionnaires, Interviews and Focus Group Discussions. Secondary data sources included books, research articles, reports by various commissions of enquiry and other relevant minutes from meetings such as records from chief's office, website searches, newspaper and magazines, publications and other relevant literature. Quantitative data was coded and keyed into the Statistical Package for Social Scientists Version 17.0 (SPSS 17.0). The data was then analysed to obtain descriptive statistics particularly frequencies and percentages and qualitative data was analysed using thematic techniques to support quantitative data. Quantitative data was presented using tables, graphs, and charts while qualitative data was presented inform of narrative reports and verbatim quotations.

Table 1. Proportional allocation of household respondents by sub-location.

\begin{tabular}{ccccc}
\hline S/N & $\begin{array}{c}\text { County } \\
\text { Assembly ward }\end{array}$ & Sub-Locations & $\begin{array}{c}\text { Total } \\
\text { Households (N) }\end{array}$ & $\begin{array}{c}\text { Sampled } \\
\text { households units (s) }\end{array}$ \\
\hline \multirow{2}{*}{1} & Sigowet & Sigowet & 985 & 27 \\
& & Kiptere & 1317 & 37 \\
2 & Tabaita & 2001 & 56 \\
& \multirow{2}{*}{ Kaplelartet } & Kaplelartet & 226 & 6 \\
& & Agoro East & 724 & 20 \\
3 & North Nyakach & Jimo East & 917 & 26 \\
& & Kandaria & 354 & 10 \\
4 & South East Nyakach & East Kadianga & 4087 & 114 \\
& TOTAL & & 10611 & 296 \\
\hline
\end{tabular}

Source: Author, 2017. 


\section{Study Findings and Discussions}

\subsection{Demographic Characteristics of Household Heads in Nyakach and Sigowet Sub-Counties of Western Kenya}

The demographic information of household heads was done through the use of questionnaires. A total of 296 questionnaires were administered to the respondents and all the questionnaires were returned meaning there was $100 \%$ response rate. The demographic information collected through the questionnaires was classified into five categories; gender, age, marital status, religion and education.

\subsubsection{Gender of Household Heads in Nyakach and Sigowet Sub-Counties of Western Kenya}

The study sought to establish the gender of 296 household heads. The respondents were thus asked to indicate their gender and the results are shown in Figure 2 .

The results in Figure 2 indicate that 213 (72\%) of respondents were males while 83 (28\%) were females. The study therefore reveals that majority of the households are headed by males as opposed to their female counter parts as the research focused on interviewing the heads of household.

The results of this study show that there is gender disparity in Nyakach and Sigowet Sub-counties with the male members of the society dominating as heads of the households therefore leaving women behind. The gender inequality portrayed through these results indicated that the cultural norms had made men take up leadership position in the society. This has been at the expense of women thereby making it difficult for females to be active participants in the decision making processes of the society.

The findings were consistent with the KDHS 2014 study which indicated that men are the major decision makers in most of the important household activities. According to Kenya Demographic and Health Survey [17], only 20\% of married women make decisions mainly on important issues such as household purchases, meaning that it mostly men who make key household decisions

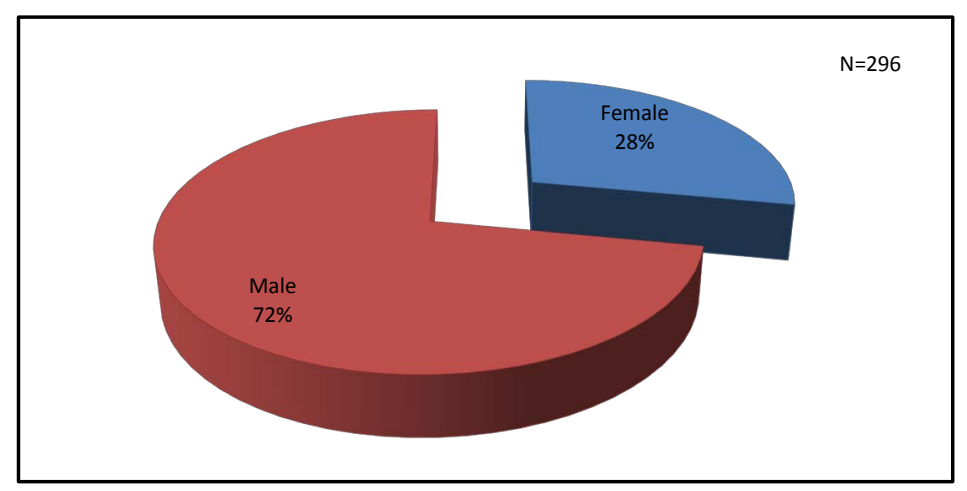

Figure 2. Gender of household heads in Nyakach and Sigowet Sub-Counties of Western Kenya. Source: Field Data (2017). 
(KNBS, 2015). The socio-economic status of men and women can be shown through ownership of assets. According to the KDHS 2014 survey more men than women own and control assets and as such, most women have to depend on men economically [17].

These findings further agree with Margaret Urban Walker who indicated that the socio-economic status of women in the society makes them vulnerable to negative impacts of conflicts and therefore making them disadvantaged [18]. Both men and women play an active role in conflicts but also get affected differently by these conflicts. Women's participation and experience in conflict can be analysed at three levels. That is, in the personal sphere, where they experience and participate in conflict as individuals, in the private sphere, where they experience conflict as mothers and wives and in the public sphere, where they interface with societal structures that limit their participation in decision making processes and peace building mechanisms.

Lack of gender balance in the decision-making process from the household and its extension to the society at large has made it difficult to have a societal approach in the management of ethnic conflicts. In as much as women are active participants at the grassroots in managing conflicts, they are normally forgotten in the formal peace process due to the cultural norms that treat them differently from men [19]. In this regard, the grass-root concerns of women are forgotten, thereby creating room for the recurrence of the conflicts.

\subsubsection{Age of Household Heads in Nyakach and Sigowet Sub-Counties of Western Kenya}

The study sought to find out the age of household heads in Nyakach and Sigowet Sub-counties of Western Kenya. The results from 296 household heads are shown in Figure 3.

The results indicated that those in the age bracket of 16 - 21 years were 38 (12.84\%) 22 - 35 years were $122(41.55 \%), 36$ - 55 years were $81(27.36 \%)$ and those above 56 - 75 years were 41 (13.85\%) and above 75 years were $13(4.39 \%)$. These findings are consistent with the 2010 Kenyan census, which cumulatively put those between ages of 15 - 55 years in the study area at $52.4 \%$ and those

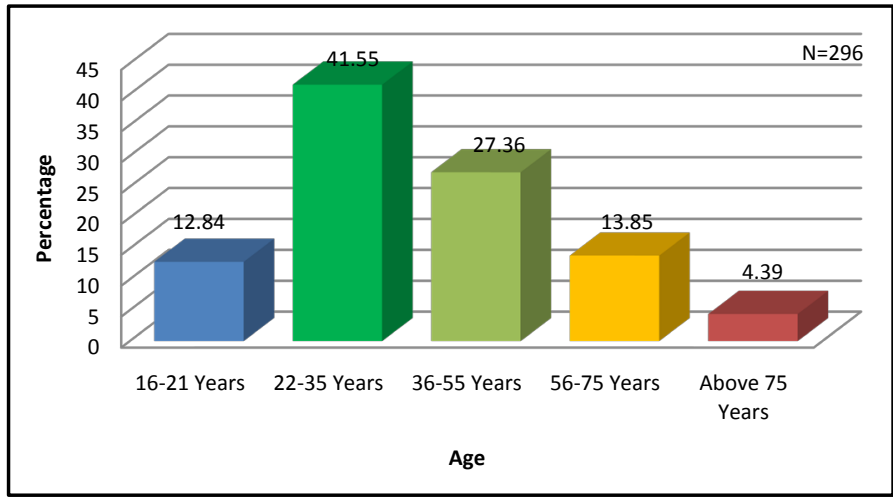

Figure 3. Age of household heads in Nyakach and Sigowet Sub-Counties. Source: Field Data (2017). 
above 55 years at $6.7 \%$ [16]. Majority of the respondents were below 55 years which is mostly considered to be the productive ages and therefore people who were directly affected socially and economically by the recurrence of the conflicts. Those above the age of 55 though not the majority had vast experience on the history of the recurrence of the conflicts. They were key in providing vital information on the recurrence of the conflicts since they had lived in the areas longer and hence understood the dynamics of the conflicts in the area of study. Age is an important factor in conflicts issues [20]. The most active participants in conflicts are youths.

Ages of 16 - 21 years which catered for $12.64 \%$ of the respondents are mainly years when people are mostly engaged in education with majority of people in high school or colleges. These categories of respondents were therefore able to give information on the impacts of the recurrent conflicts on education as this matter directly affected them. The respondents of ages $22-35$ years and $36-55$ years cumulatively accounted for $78.9 \%$ of the respondents. Majority were composed of young people and middle-aged people mostly job seekers, working class or those hoping to get married and settle down and those who are married. These are the most active members of the society who drive the economy and are the most affected by the conflicts. These age categories were therefore important in this study since these groups of respondents could give information about the effects of conflicts on the economy as well as on the welfare of the members of the society as a whole.

According to the Kenya National Bureau of Statistics, Kenya has a high dependency in the rural areas with the child dependency ratio being 0.926 and aged dependency ratio being 0.082 . Nyakach and Sigowet Sub-counties being rural based have high dependency ratio [21]. Most members of the society below 22 years and those above 55 years also depend on this age category. It is imperative that people between 22 - 55 years bare the economic burden of the community and therefore the most affected by conflicts In this study it was important to classify the respondents by age since youths are often active participants in conflicts. The African Youth Charter defines youth a person between the ages of 15 to 35 [22]. In this study, the African youth Charter definition has been the basis of defining youths. Majority of the respondents were youthful and understood the dynamics of the conflicts in the study area.

\subsubsection{Marital Status of Household Heads in Nyakach and Sigowet Sub-Counties of Western Kenya}

The study sought to determine the marital status of 296 household heads in Nyakach and Sigowet Sub-counties of Western Kenya. The results were as indicated in Figure 4.

The results in Figure 4 show that from the 296 respondents interviewed; 24 (8.11\%) were single, 239 (81.08\%) were married, and 20 (6.76\%) were divorced or separated and 13 (4.05\%) widows or widowers. The finding of the study was consistent with the KDHS 2014 survey which indicated that $73 \%$ of women are 
married by age of between age 19 to 34 years and $83 \%$ of men get married at the ages of 25 to 35 years [17]. The findings of the study indicate that most adults above 20 years are married. Since majority of the respondents are married, this indicates that these respondents were mature people and responsible members of the community. They are affected by conflicts and as such were aware of the socio-economic factors surrounding the conflicts as this had a direct bearing on their lives as people who have families.

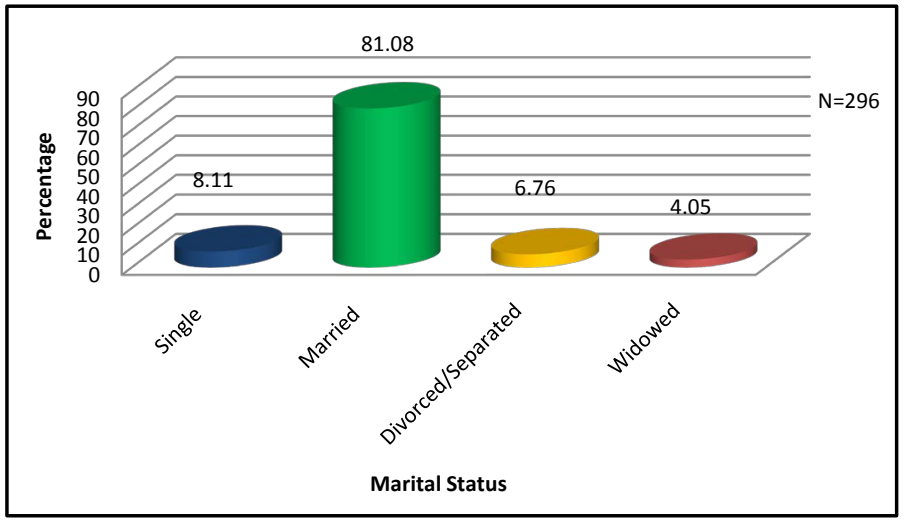

Figure 4. Marital status of household heads in Nyakach and Sigowet Sub-Counties of Western Kenya. Source: Field Data (2017).

\subsubsection{Religion of Household Heads in Nyakach and Sigowet Sub-Counties of Western Kenya}

The study sought to establish the religion of the household heads, they were asked to indicate their religions which gave rise to the results shown in Figure 5.

Results in Figure 5 show that out of the total 296 respondents, 210 (71\%) of respondents were Christians, 32 (11\%) were Muslims while 31 (10\%) followed African traditions/religion and $23(8 \%)$ indicated that they belonged to other religions which included Hindus, Pagans and non-believers. From the results it is therefore clear that majority of the respondents in Nyakach and Sigowet Sub-counties were Christians. In the study of ethnic conflicts, religion is an important factor since religious leaders are often seen to be playing an important role in ensuring that the communities are peaceful. Religion appeals to people differently and as such the use of religion to foster peace is possible as religion as the moral value of peace, love and cohesion are easily awaken through religious teachings. The use of religion to preach peace and morality is normally led by the clergy who are in many occasions held with high regard in the communities where they live. Christianity and Islam in particular have important teachings on peace and therefore having communities where people are religious impacts directly or indirectly on issues of conflicts as well as peace.

The role of religion in preventing conflicts was further supported by the evidence from the faith based organizations that were involved in peace building within the study area. These included The Catholic Justice and Peace Commission, Lutheran Church, the Seventh Day Adventist Church (SDA), the Catholic 


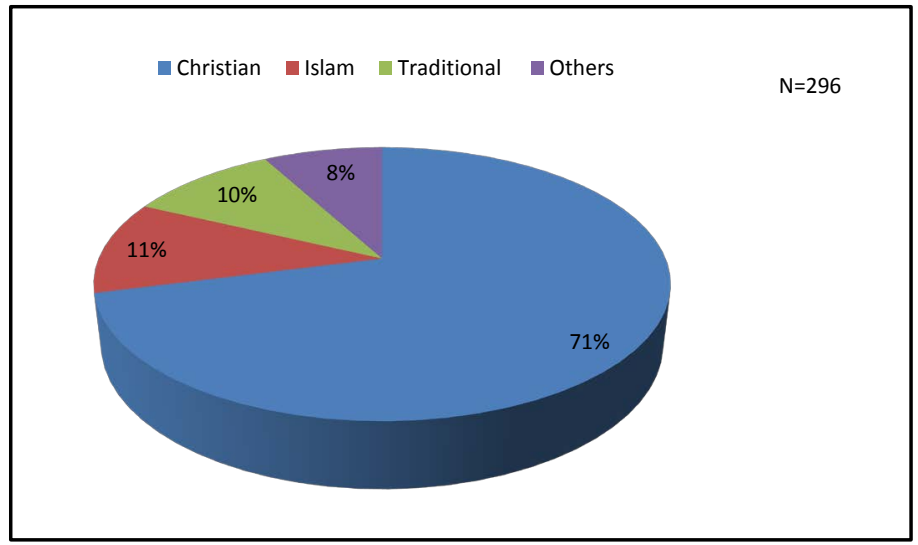

Figure 5. Religion of household heads in Nyakach and Sigowet Sub-Counties of Western Kenya. Source: Field Data (2017).

Church and the Anglican Church as it emerged from Interviews. The Catholic Church was actively involved in peace building activities through the Catholic Justice and Peace Commission. One of the participants in the FGDs conducted in Nyakach Sub-county indicated that religious organizations were also involved in providing relief food and shelter to affected communities during ethnic clashes especially in Cherwa border area, the Church provided shelter to families whose houses were torched during the conflicts while preaching peace to the locals to coexist peacefully. In another FGD held in Sigowet, it emerged that the Sigowet Lutheran Church on several occasions hosted consultative peace meetings and DPC meetings that were all meant to foster peace in the area.

\subsubsection{Educational Level of Household Heads in Nyakach and Sigowet Sub-Counties of Western Kenya}

The study sought to determine the educational level of household heads Nyakach and Sigowet Sub-counties of Western Kenya. Education levels were categorised as; no formal education, Primary level, secondary level and post-secondary level. The results are as given in Figure 6.

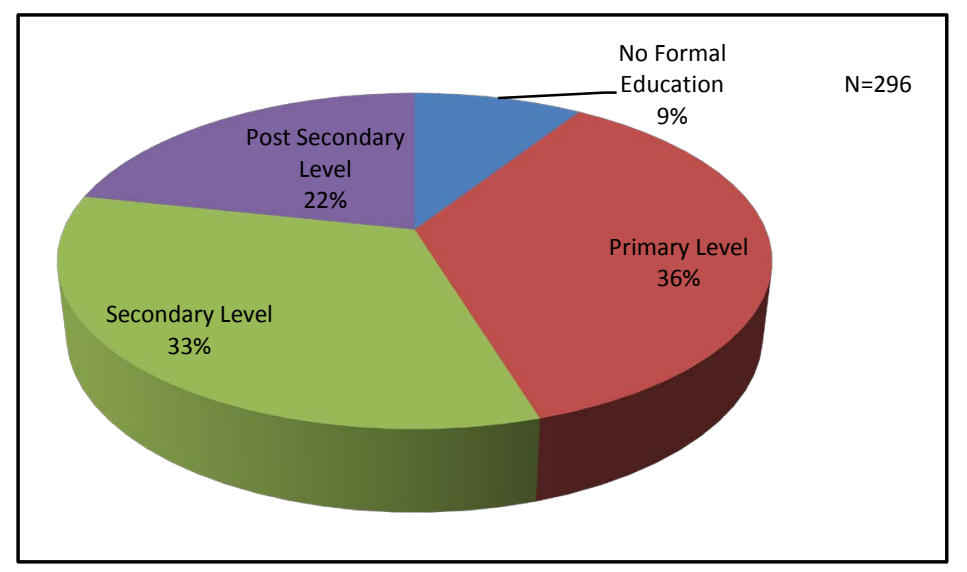

Figure 6. Education levels of household heads in Nyakach and Sigowet Sub-Counties of Western Kenya. Source: Field Data (2017). 
The results revealed that out of the total 296 household heads, 65 (22\%) had post-secondary education, 98 (33\%) had secondary education, and 106 (36\%) had primary education while 27 (9\%) had no formal education. Based on these findings, cumulatively, $69 \%$ of the household heads only had basic education and did not have any training and marketable skills. The lack of marketable skills by majority of the respondents therefore has a direct implication on their socio-economic status. Education has a direct implication on the livelihood of people as well as their ability to be employed which is a factor that can lead to poverty [23]. Since the majority of the population is made up of young people (below 35 years), low educational attainments make them vulnerable to active conflicts as supported by the Akinyi and others on electoral violence in Kenya. [10]. The authors further opined that many youths with low educational attainments were easily influenced to participate in politically motivated conflicts in exchange of hand-outs of as low as 200 Kenya Shillings. Therefore, education affects the socio-economic status of people and can influence their participation in conflicts.

\subsection{Duration of Stay by Household Heads in Nyakach and Sigowet Sub-Counties of Western Kenya}

The study sought to establish the duration of stay for respondents in Nyakach and Sigowet sub-counties of Western Kenya. The results are given in Figure 7.

The findings of the study revealed that out of the 296 household heads, 241 $(81.3 \%)$, had lived in the area for more than 10 years, $34(11.59 \%)$ had stayed in the area for a period of between five to ten years and $21(7.11 \%)$ had stayed in the area for less than three years. Duration of stay in the area was important in this study because it would inform on whether or not the respondents had experienced the recurrent conflicts. Since parts of the study area such as Sondu were cosmopolitan it was important to understand the duration of stay so as to account for the people who might have not stayed in the area for long based on the fact that they might have migrated into the area for recently either for work or because they might have acquired land and settled in the area recently.

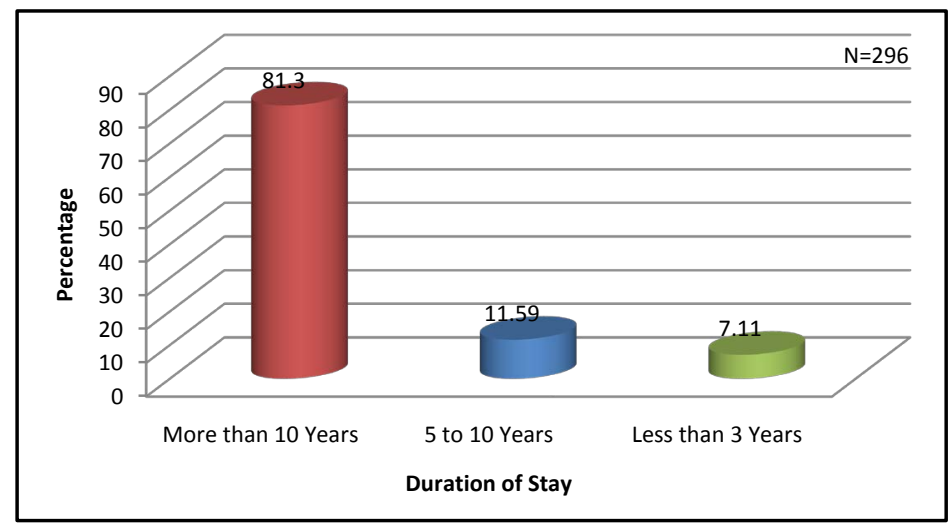

Figure 7. Duration of stay for household heads in Nyakach and Sigowet Sub-Counties of Western Kenya. Source: Field Data (2017). 
The rise in local population and the increasing number of people migrating into an area through land buying and other business related activities have put pressure on the livelihood systems and pitted livelihood groups against one another and as a result of these socio-economic pressures, ethnic conflict have become inevitable [24]. This has been the situation in the Darfur conflicts where for the last 40 years, environmental pressures, and population pressure coupled with political marginalization have led to the creation of ethnically distinct militias that have led to the recurrent conflict in the region [25]. Therefore, increased pressure brought about by population explosion coupled with competition for resources is a major trigger for ethnic conflicts and related violence.

\subsection{Whether Household Heads Have Experienced Inter-Ethnic Conflicts in Nyakach and Sigowet Sub-Counties of Western Kenya}

The study sought to establish whether Household heads had experienced inter-ethnic conflicts in Nyakach and Sigowet Sub-Counties of Western Kenya. The 296 respondents were asked to indicate whether or not they had experienced conflicts in the area where they are staying. The results are given in Figure 8.

The results indicated that 278 (94\%) of the household heads had witnessed conflicts while $18(6 \%)$ had not experienced conflicts in the area. Therefore the majority of respondents had experienced conflicts within the area. These findings agree with a study by Akinyi-Dar and others which designated that the communities from the two sub-counties had been affected by recurrent conflicts for many years, these conflicts have been more common since 1992 and have since then recurred over the years and thus justifying why majority of the respondents has witnessed conflicts [10]. Only 6 percent of the household heads indicated that they had not experienced the conflicts in the study area. The argument could be attributed to the fact that some of the respondents may have settled in the area more recently and as such may have not experienced the periodical conflicts.

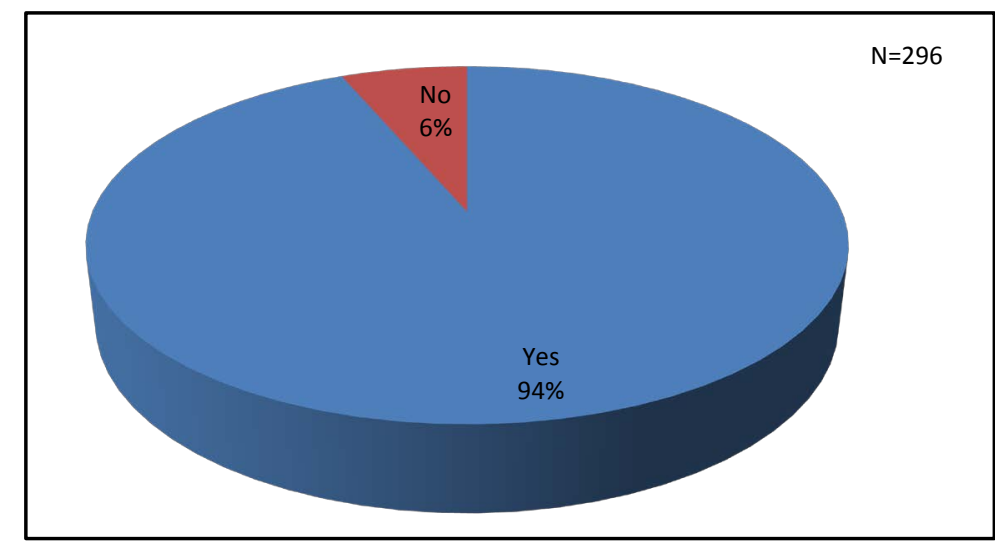

Figure 8. Whether household heads have experienced inter-ethnic conflicts experienced in Nyakach and Sigowet Sub-Counties. Source: Field Data (2017). 
The responses from the four FGDs and interviews from the 48 (100\%) key informants also revealed that recurrence of conflicts was common in the area. The conflicts affected various members of the community either directly or indirectly causing various impacts. Government officials such as the police and chiefs' reported that government intervention had been important in reducing the incidences of conflicts in the area.

In an interview, a chief from Nyakach Sub-county indicated that:

Following the recurrent conflicts in the border areas of Sondu, a new police post has been built in the area and more police officers deployed to curb the incidences of the conflicts (Interview with Chief, $5^{\text {th }}$ April 2017).

All the 14 chiefs who were interviewed indicated that the Anti-Stock theft Police Unit (ASPU) and the Administration Police (AP) had done good work in curbing as well as containing the conflicts in the area especially with regard to cattle rustling. It emerged from one of the men's FGDs that the increased number of police posts had not helped to fully bring to a halt the issue of ethnic conflicts in the area due to the challenges that the police face in the process of doing their work. In support of the findings a report by the Kenya National Commission of Human Rights indicated that, among the challenges the police have to grapple within the process of doing their work include; corruption, poor working and living conditions by the police, poor coordination among various police departments and the slow pace of reforms in the police [26].

\subsection{Number of Times the Conflicts Were Experienced by Household Heads in Nyakach and Sigowet Sub-Counties}

The study sought to determine the numbers of times the household heads had experienced conflicts in the study area. The results are as given in Figure 9.

The results revealed that out of 296 respondents 269 (90.88\%) indicated that they had experienced conflicts more than once, $14(4.73 \%)$ had experienced the conflicts only once and $13(4.39 \%)$ indicated that they had not experienced any conflicts in the area. The fact that majority of the respondents have experienced the conflict more than once is an indication that the conflicts in Nyakach and Sigowet Sub-counties have been recurring over the years. The most affected have been the natives of the area. There were those household heads who had experienced the conflicts only once and those who had not experienced the conflicts at all, which was attributed to their length of stay in the study area. The household heads who indicated that they had not experienced the conflicts had stayed in the study area for less than three years and as such may have not been affected by the conflict that occurred in the area since 1992.

During the interviews, all the 14 chiefs agreed that recurrence of inter-ethnic conflicts was a common factor in the area and that these conflicts would occur at any time. The 10 the officials' from the civil society organizations who were interviewed also concurred that the conflicts in the area were recurrent. The FGDs also brought into perspective the issue of recurrence of inter-ethnic conflicts in the area especially in border areas of the two sub-counties. 


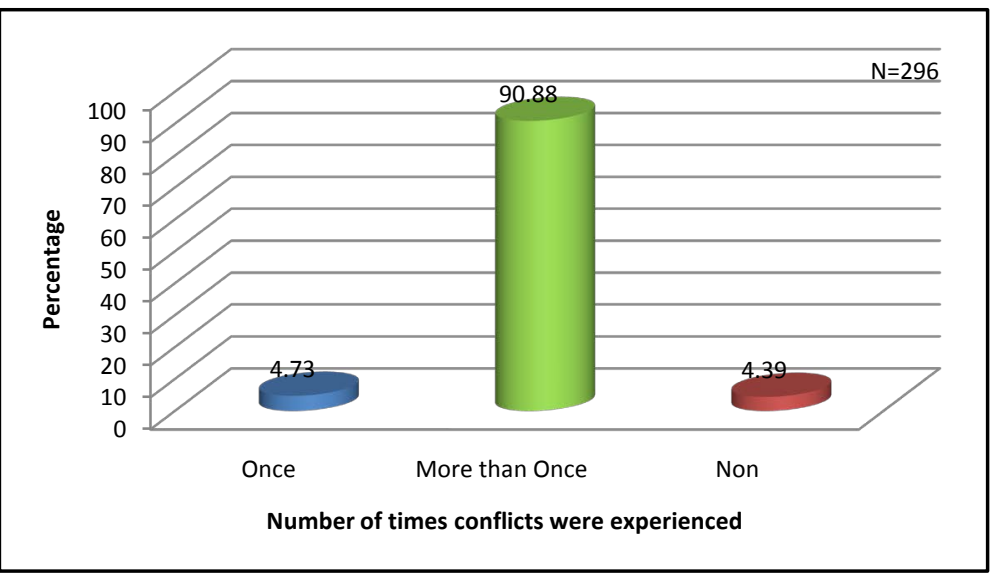

Figure 9. Number of times the household heads had experienced conflicts in Nyakach and Sigowet Sub-Counties. Source: Field Data (2017).

\subsection{Duration of the Conflicts in Nyakach and Sigowet Sub-Counties of Western Kenya}

The study sought to determine the duration the conflicts took before peace returns in the study area. The results are as given in Figure 10. The results indicated that out of the 296 respondents, 139 (47\%) of the respondents stated that the conflicts took fewer days, which is less than a week before calm returned in the study area, 104 (35\%) indicated that the conflicts lasted for few weeks while $53(18 \%)$ of the respondents indicated that that the conflicts lasted for several months.

The police officers, chiefs and the ASTU officers who were interviewed agreed with the majority of household heads that the conflicts only took a few days as most of the security apparatus in the area were often alert and ready to deal with conflicts in the area. An interview with a police officer revealed an emphatic case as the officer indicated:

Immediately there are reports of ethnic clashes at the border points, we are always aware that these tension can escalate as either community may keep on attacking the other in revenge missions, something that can make security situation in the area worse, therefore as police officers we normally go to the border points to create a buffer zone so that nobody crosses the border to attack their enemies on the other side and therefore we are able to calm the situation within a day or two, although tension normally remains high for weeks (Interview with a Police Officer, $8^{\text {th }}$ April 2017).

Another officer from the Anti-stock theft Police Unit also stated that:

We normally patrol the borders because these are the areas where the conflicts are common. Once the conflict occur we normally swing into action immediately to get back the animals that have been stolen and in the process we work closely with other security agencies in the area to make sure that the conflict is contained within a few days (Interview Anti-stock theft Unit Police Officer, $12^{\text {th }}$ April 2017). 


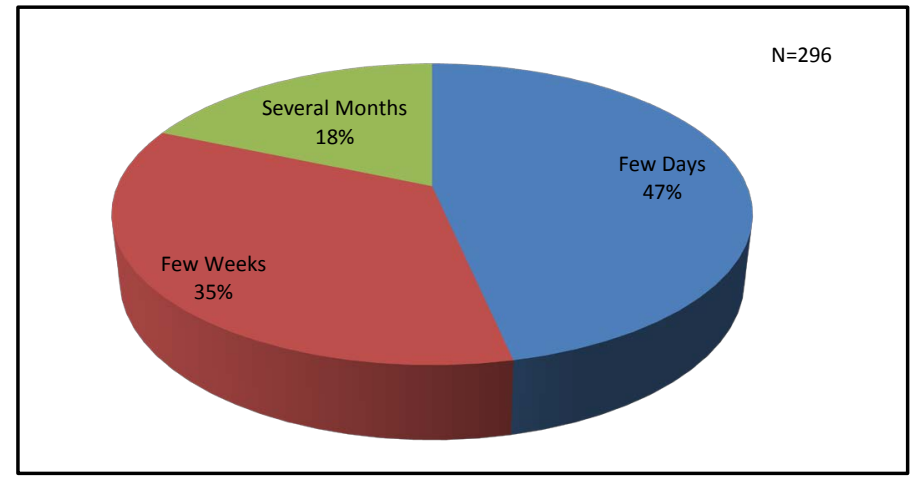

Figure 10. Duration of conflicts in Nyakach and Sigowet Sub-Counties of Western Kenya. Source: Field Data (2017).

The presence of several police posts in the area as well as the availability of both Administration Police and the Anti-Stock Theft Police Unit has made it possible for the security forces to deal with the conflicts fast and restore peace in the area. It is however important to note that, after the immediate threats have been dealt with, it is a norm that no community based-initiatives are put in place to deal with the root causes of conflicts, but rather the peace that normally returns in the area is the negative peace normally imposed by security agencies [26]. The lack of community-based initiatives therefore lead future recurrent conflicts.

\subsection{Areas Prone to the Conflicts}

The study sought to establish areas more prone to the Conflict in Nyakach and Sigowet sub counties. The results were as shown in Figure 11.

The results indicated that $208(70.27 \%)$ indicated that most of the conflcits were witnessed in the border areas between the two subcounties, 39 (13.18\%) indicated that Sigowet side was more prone to the conflicts while 49 (16.55\%) indicated that Nyakach side was more prone to the conflicts. In this sence therefore, majority of the respondents were of the opinion that conflicts were more common in the border of the two sub-counties which was also the border of the two ethnic communities.

An official from Kenya Red Cross also supported the argument that the conflicts are normally common along the border areas with many people being affected by the conflicts from both Nyakach and Sigowet Sub-counties. The sentiments from the Red Cross official were echoed by the Chiefs who were also interviewed during the study.

One of the participant in the FGD opined that:

Most of the areas that are known to be hotspots for conflicts are border areas which mainly include border areas like Sondu, Obingo-Sisiwet areas and Cherwa area. These places are hotspot areas due to the activity of cattle rustling that goes on in these places. Border areas are battle grounds because those who steal animals can easily get them into Sigowet side without being traced easily (FGD Participant, $8^{\text {th }}$ April 2017). 


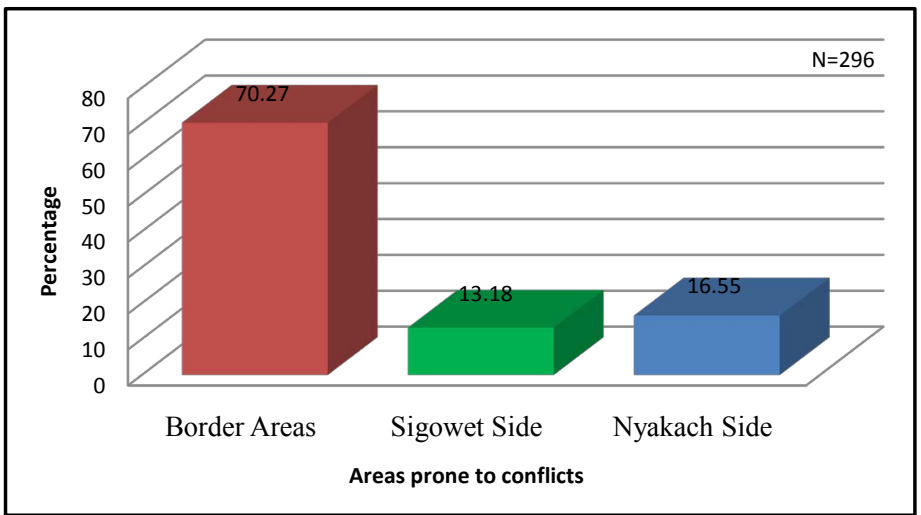

Figure 11. Areas prone to the conflict in Nyakach and Sigowet Sub-Counties. Source: Field Data (2017).

These findings are supportive of a report by Akinyi-Dar and others which revealed that conflicts between bordering ethnic communities was a common phenomenon in western Kenya as witnessed in Nandi-Kericho border, Sotik-Borabu border and Kakamega-Nandi border [10]. The findings further agree with a study by Masaka and others which indicated that in as much as these conflicts affect communities from either side of the ethnic borders, the most affeted area are normally those areas where both communities live and it is in these areas where killings, burning of houses and other acts that fuel these conflicts happen. It is in this regard, that more needs to be done especially along border areas to ensure communities live together in harmony [27]. Traditional and community-based solutions such intermarrige between ethnic groups, sharing of social amenities such as schools and other resources should be used by the communities to enhance relationships so as to build stronger cohesion among communities that border one another.

\subsection{Frequency of the Conflicts}

The study sought to establish the duration taken between one conflict and another as far as recurring of conflict in the study area, is concerned. The results were as shown in Figure 12.

The results revealed that 153 (52\%) of the respondents were of the opinion that conflicts occurred after several months, $110(37 \%)$ indicated that the conflicts occurred every year, $18(6 \%)$ indicated that the conflicts occurred monthly while $15(5 \%)$ indicated that the conflicts occurred weekly. In support of these results, the Chiefs indicated that most of the conflicts occurred after several months, for example records from the office of the one of the Chiefs specified that in between 2014 and 2016 there were two incidences of serious ethnic clashes in the area where people were killed, livestock were stolen and people were displaced. The records from the office of the chief indicated that the conflict occurred in March 2014 and also in April 2015, causing a lot of suffering to the people who were affected. 


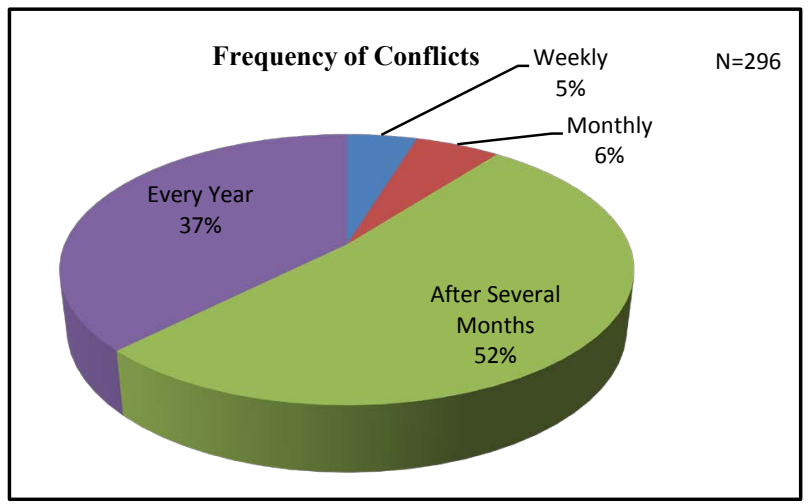

Figure 12. Frequency of the conflicts in Nyakach and Sigowet Sub-Counties. Source: Field Data (2017).

\subsection{Perpetrators of Inter-Ethnic Conflicts in Nyakach and Sigowet Sub-Counties of Western Kenya}

The study sought to establish the perpetrators of inter-ethnic conflicts in Nyakach and Sigowet Sub-Counties. The 296 respondents gave their feedback on the extent to which they agreed or disagreed with politicians, youths, external perpetrators and vigilante groups as perpetrators of inter-ethnic conflicts in Nyakach and Sigowet Sub-counties. The results are as indicated in Figure 13.

The results in Figure 13 show that 107 (69.9\%) of the respondents agreed that politicians were major perpetrators of inter-ethnic conflicts in Nyakach and Sigowet Sub-counties while 16 (5.4\%) were of contrary opinion; 205 (69.3\%) of the respondents also indicated that youths were another group that perpetrated the conflict in the study area and 250 (84.5\%) of the respondents opined that cattle rustlers were the major perpetrators of the conflict in the study area. External perpetrators and vigilante groups were not viewed as perpetrators as evident in the results whereby $152(54.1 \%)$ and $168(56.8 \%)$ of the respondents disagreed respectively as seen in Figure 13. The results further indicate that $215(72.6 \%)$ of the respondents knew the perpetrators as compared to 39 (13.2\%) of the respondents who indicated that they did not know.

These results were consistent with the findings from the key informants and FGDs, where it emerged that most of the youths who were unemployed were easily targeted by those from the political class to cause mayhem in the area especially during electioneering periods. In an interview by one chief's from Nyakach Sub-county it emerged that the youths are the most active participants in ethnic conflicts in the area as they were mostly involved in cattle rustling. Similar claims came out during one of the FGDs.

The findings were in agreement with a study by Biko who signposted that most youths were vulnerable to manipulation and participation in violet conflicts due to poverty and unemployment as politicians would give them hand-outs and play the ethnic card so as to get them involved in politically motivated violence [28]. The study also agreed with another study by Oyugi who revealed that politicians often used the ethnic ideology to get political support 


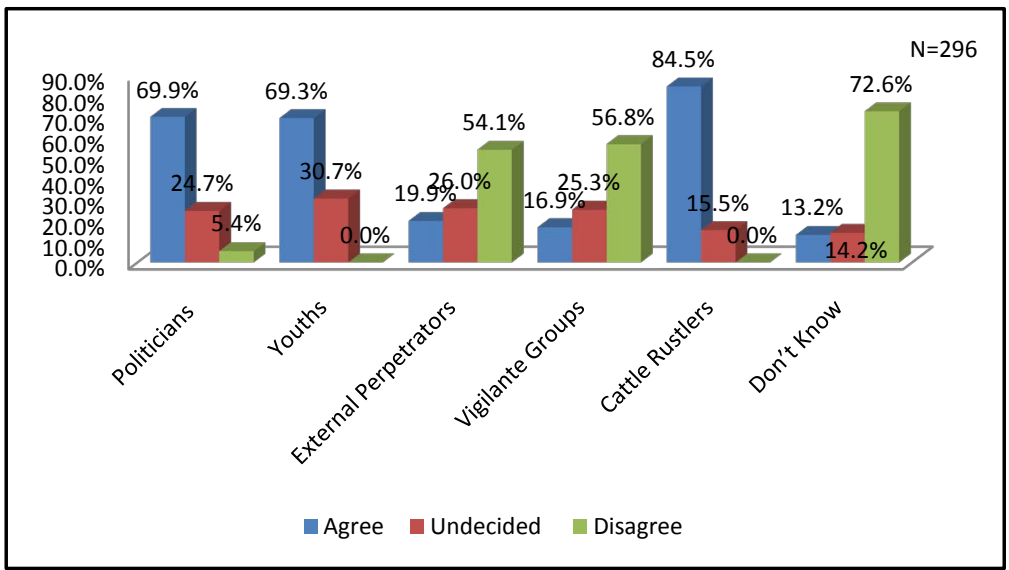

Figure 13. Perpetrators of inter-ethnic conflicts in Nyakach and Sigowet Sub-Counties of Western Kenya. Source: Field Data (2017).

base and further their personal interest at the expense of peaceful coexistence among members of the community [29]. Politicians tend to use stereotypes to portray the "other" community as an enemy of "our" community, something that ends up appealing to the ethnic emotions of those to whom the message is targeted thereby creating the image of "us" versus "them" thereby leading to a situation where people attack the other community for political reasons as witnessed in 1992, 1997 and 2002 and 2007 elections [10].

In the run up to the August 2017 general elections, Sondu/Kericho border and Kipsigis/Kisii border within the environs of Nyakach and Sigowet Sub-Counties had been mapped as hotspot areas for electoral related violence by the Interior Ministry, National Police service and National Cohesion and Integration Commission [30]. Some of the reasons given by these government agencies for mapping these areas as a hotspots for violence included pre-election hate speech, zoning areas, incitement, engaging organised criminal gangs, disruption of opponent campaign meetings and post-election activities which include but not limited to, refusal to accept results by aspirants, disruption of the process of counting votes, arson, vandalism as well as interference with government installations [30]. It is therefore important to note that, politician leadership struggles in the form of violence by perpetrated political leaders with the help of poor youths played a crucial role in the conflicts in the area.

Cattle Rustlers also emerged in the study as major perpetrators of ethnic conflicts as by 250 (84.5\%) of household heads. The FGDs and key informant interview results indicated that the conflicts are normally triggered when raiders from one community attack and steal cattle from the other leading to confrontation between the communities in the process of tracing the animals, hence violence. It also emerged from the FGDs that cattle rustlers in the area had evolved to the extent that livestock raiding had become a commercial activity.

Cattle raiding between the Luo and the Kipsigis has been a cultural activity and has occurred over the years in Nyakach and Sigowet Sub-counties. The two 
communities coexist despite the incidences of cattle rustling [10]. However, the evolution of livestock raiding into a commercial and criminal activity involving criminal gangs, business persons and politicians led to incidences of violence as the cattle raiders became more brutal with cattle rustling becoming more rampant in the area.

The findings agree with a study by Schilling and others which revealed that commercialization of livestock raiding in which wealthy businessmen, politicians, traders and local people pursue economic objectives, has contributed to more violent confrontation between communities affected by the conflicts [31]. In this regard, there are criminal elements who steal cattle from their own communities and sell them to people in the other community hence causing violent confrontation between members of the two communities. It is also important to note that, most of the people involved in cattle rustling are the youths who are poor and jobless and who look for ways to meet their daily needs.

\subsection{Types of Inter-Ethnic Conflicts in Nyakach and Sigowet Sub-Counties of Western Kenya}

The study sought to establish the types of the inter-ethnic conflict in the study area. The results were as presented in Table 2.

Based on the findings in Table 2 the study found out that that the major type of ethnic conflicts in Nyakach and Sigowet Sub-counties was cattle raiding as indicated by 259 (87.5\%) of the household heads, 19 (6.4\%) were undecided while $18(6.1 \%)$ strongly disagreed. These findings were supported by the data from FGDs where one of the respondents noted that;

Most of the violence often erupted from Nyakach after cattle rustlers from Sigowet sub-county raided Villages in Nyakach to steal livestock. The Luos from Nyakach would often go to the Sigowet side of the border in the effort to trace and recover their stolen livestock and if they failed to get their cattle, they would also forcefully take animals from their neighbours which would lead to the chaos as the people whose animals are to be taken by force would always fight back to prevent this from happening (An FGD participant, $1^{\text {st }}$ April 2017).

Table 2. Types of inter-ethnic conflicts in Nyakach and Sigowet Sub-Counties of Western Kenya.

\begin{tabular}{ccccccc}
\hline $\begin{array}{c}\text { Types of } \\
\text { Conflicts }\end{array}$ & $\begin{array}{c}\text { Strongly } \\
\text { Agree }\end{array}$ & Agree & Undecided & Disagree & $\begin{array}{c}\text { Strongly } \\
\text { Disagree }\end{array}$ & Total (N) \\
\hline $\begin{array}{c}\text { Cattle } \\
\text { raiding }\end{array}$ & $259(87.5 \%)$ & $0(0 \%)$ & $19(6.4 \%)$ & $0(0 \%)$ & $18(6.1 \%)$ & $296(100 \%)$ \\
$\begin{array}{c}\text { Revenge } \\
\text { attacks }\end{array}$ & $125(42.2 \%)$ & $152(51.4 \%)$ & $(0) 0 \%$ & $19(6.4 \%)$ & $(0) 0 \%$ & $296(100 \%)$ \\
$\begin{array}{c}\text { Politically } \\
\text { instigated } \\
\text { violence }\end{array}$ & $71(24.0 \%)$ & $97(32.8 \%)$ & $96(32.4 \%)$ & $22(7.4 \%)$ & $10(3.4 \%)$ & $296(100 \%)$ \\
\hline
\end{tabular}

Source: Field Data (2017). 
Another Respondent noted that;

The issue of cattle theft between the Luos and Kipsigis in Nyakach and Sigowet was more complex than many people want to put it. Cattle rustling in this area has become an economic activity with criminals from both Nyakach side and Sigowet side collaborating to steal animals from their communities and selling these animals to local butcheries. Many stolen animals that are stolen are never recovered because they are never there to be recovered. Bandits mostly from Nyakach have their collaborators from Sigowet side with who they collude to steal animals from specific homesteads that that these criminals help identify, once these animals are stolen they are sold to owners of butcheries who are also involved in the business of stealing animals leaving communities fighting yet the real perpetrators of the problems are both Luo and Kipsigis communities (Interview with Uhai Lake Forum Organization Representative, $10^{\text {th }}$ April 2017).

Akinyi-Dar and others agreed with the findings of this study as the report indicated that the Kipsigis community have cultural attachment to cattle raiding based on the fact that they are agro-pastoralist community and normally tend to view livestock as a source of wealth [10]. The findings of this study were also consistent with those of Kaprom who notes that cattle rustling has both social and economic aspects that make it the major cause of conflicts among various pastoralist communities [32]. In Kenya, cattle are seen by many people as a major source livelihood, a symbol of wealth as well as social prestige, therefore, people who engage in stealing livestock do it for the purposes for getting wealth. The motivation for cattle raiding among pastoral communities in based on poverty, need for payment of dowry and accumulation of wealth as seen from the Pokot and Turkana conflicts [31].

Revenge attacks shown Table 2 also emerged as a factor that led to the recurrence of Inter-ethnic conflicts which was also supported by 277 (93.6\%) of the respondents as compared to $19(6.4 \%)$ who gave a contrary opinion. Since the conflicts in Nyakach and Sigowet sub-counties mainly involved two ethnic communities, the study established that youths from either community would always go to the neighbouring community and attack people as a way of paying back what had been done to them earlier. The argument was supported by the results from FGDs where one of the participants noted that;

Conflicts normally escalate especially when youths from Luo community decide to go and raid villages Sigowet and burn houses or kill thereafter a raid by people from the Sigowet side. The issue of revenge is often common from either side and without the police putting a buffer zone between the youths from both communities it the conflicts in this area would be worse (FGD participant, April $\left.8^{\text {th }} 2017\right)$.

These finding are consistent with the argument of Clark in which he states that revenge attacks often fuel ethnic conflicts and to more serious impacts as witnessed during the 1994 Tutsi genocide in Rwanda when the RPF opted to kill Hutus as a way of avenging the Tutsis who were killed during the 100 days of 
war between the Hutu and Tutsi in which over 800,000 people lost their lives [33].

The results of this study as seen in Table 2 also indicated that politically instigated violence was another type of conflict that was common in the study area as supported by $168(56.8 \%)$ of the household heads, only to $32(10.8 \%)$ of the household heads did not agree with this types of conflict. These results were consistent with findings from FGDs. During one of the FGDs conducted in Nyakach Sub-county, 9 out of 10 respondents agreed that politics had a lot to do with ethnic conflicts in the study area. The respondents from FGDs specified that the election periods, were the times of highest tension in the area.

These findings were consistent with the assertions by Peters, who argued that, in Kenya every election campaign period is marred with episodes of political incitement, land issues, ethnic tensions and ethnic polarizations which eventually lead to serious violent clashes between ethnic groups during the campaigns and after the election [34]. Further, Oyugi stated that conflicts in Nyakach and Kericho west districts, during and after the 1992, 1997, and 2002 elections were as a result of ethnic balkanization based on political affiliations [29]. In 2007, the tide changed with the Kalenjin, the Luo and the coastal communities supporting ODM fighting against the Kikuyu, the Kisii, the Kamba and other Communities that were perceived PNU supporters [10]. Political activities such as elections and political electioneering processes are a key driver of ethnic conflicts, as political party aspirants take advantage of unemployed and underemployed young people under the to cause mayhem areas that are considered to be multi-ethnic especially borders areas.

\section{Conclusion}

The study concludes that inter-ethnic conflicts in Nyakach and Sigowet Sub-Counties are attributed to socio-cultural and political issues that affect the communities from the two sub-counties. There is the culture of cattle rustling that has largely contributed to the conflicts; this has been made worse by the geopolitical dynamics of the two sub-counties. Conflicts are especially common along the border areas due to the socio-cultural differences that have been made worse by the political actors who have more often than not used their influence in the society to sow seeds of discord.

\section{Recommendation}

The study recommends that all the major causal factors for conflicts be addressed from the grass roots. Local players who have better understanding of the historical dimensions of the conflicts such as the council of elders from both Luo and Kipsigis communities with the help and goodwill of the political actors. More energy should be directed to the areas bordering the two communities. The study further recommends that intercommunal cohesion be done in a more robust manner so that cultural exchanges between communities can bring unity 
as opposed to violence, this can be done based on the fact that these communities have shown the possibility of living together in harmony as seen from the trading activities in Sondu market during peaceful period. The study further recommends that cattle rustling which is a cultural activity be dealt with by the elders who are the custodians of the culture and this retrogressive activity be criminalised at communal level so that government agencies can find it easy to reinforce the law criminalising this and other related illegal activities that have for years acted as triggers of violent conflicts in the area.

\section{Acknowledgements}

The researchers appreciate the support from the entire School of Disaster Management and Humanitarian Assistance (SDMHA) during this research. More specifically we thank the academic staff at the Department of Peace and Conflict Studies for the support during the research. We would also like to thank all the respondents for the valuable information that made this study a success.

\section{Conflicts of Interest}

The authors declare no conflicts of interest regarding the publication of this paper.

\section{References}

[1] Aapengnuo, C.M. (2010) Misinterpreting Ethnic Conflicts in Africa. Africa Center for Strategic Studies, Washington DC.

[2] Walter, B.F. (2004) Does Conflict Beget Conflict? Explaining Recurring Civil War. Journal of Peace Research, 41, 371-388. https://doi.org/10.1177/0022343304043775

[3] UN (2003) Sociocultural Baises and Discrimination.

[4] Negash, M.H. (2015) Ethnic Identity and Conflicts: Lessons from the Kosovo Crisis. European Scientific Journal, 11, 303-318.

[5] Ramsbotham, O., Miall, H. and Woodhouse, T. (2011) Contemporary Conflict Resolution. Polity, Cambridge.

[6] Brown, S. (2004) Theorising Kenya's Protracted Transition to Democracy. Journal of Contemporary African Studies, 22, 325-342. https://doi.org/10.1080/0258900042000283494

[7] BBC (2003) Impact of Hate Media in Rwanda. http://news.bbc.co.uk/2/hi/africa/3257748.stm

[8] Oyugi, W.O. (1997) Ethnicity in the Electoral Process: The 1992 General Elections in Kenya. African Journal of Political Sciencel Revue Africaine de Science Politique, 2, 41-69.

[9] Akiwumi, A.M. (1999) Report of the Judicial Commission Appointed to Inquire into Tribal Clashes in Kenya. The Commission, Nairobi.

[10] Akinyi-Dar, N.P., Kabongah, G.O., Otieno, O., Leo, P., Kamau, M., Onyango, M., Wepundi, M. and Obiri, J. (2011) The Invisible Violence in Kenya: A Case Study of Rift Valley and Western Regions. Konrad Adenauer-Stiftung, Berlin.

[11] Maina, K. (2010) Speech Power and Violence: Hate Speech and Political Crisis in Kenya. https://www.ushmm.org/m/pdfs/20100423-speech-power-violence-kiai.pdf 
[12] Geertz, C. (1963) The Integrative Revolution: Primordial Sentiments and Civil Politics in the New States. In: Old Societies and New States. The Quest for Modernity in Asia and Africa, Collier-Macmillan, London, 105-157.

[13] Vanhanen, T. (1999) Domestic Ethnic Conflict and Ethnic Nepotism: A Comparative Analysis. Journal of Peace Research, 36, 55-73. https://doi.org/10.1177/0022343399036001004

[14] Kothari, C.R. (2004) Research Methodology: Methods and Techniques. New Age International (P) Limited, New Delhi, India.

[15] Mugenda, O. and Mugenda, A. (2003) Research Methods: Quantitative and Qualitative methods. Revised in Nairobi.

[16] Statistics, K.N.B.O. (2010) The 2009 Kenya Population and Housing Census. Vol. 1. Kenya National Bureau of Statistics.

[17] KDHS (2014) Health Survey 2014: Key Indicators. Kenya National Bureau of Statistics (KNBS) and ICF Macro.

[18] Walker, M.U. (2009) Gender and Violence in Focus: A Background for Gender Justice in Reparations. In: Rubio-Marin, R., Ed., The Gender of Reparations. Unsettling Sexual Hierarchies While Redressing Human Rights Violations, Cambridge University Press, Cambridge, 1-17.

[19] Lorenz, J. (2004) Role of Women and Men in Violent Conflicts.

[20] Tierney, K.J., Lindell, M.K. and Perry, R.W. (2002) Facing the Unexpected: Disaster Preparedness and Response in the United States. Disaster Prevention and Management: An International Journal, 11, 222-222. https://doi.org/10.1108/dpm.2002.11.3.222.1

[21] SID \& KNBS (2013) Exploring Kenya's Inequalities: Pulling a Part of Together? Abridged Report.

[22] African Union (AU) (2006) African Youth Charter. African Union Commission, Banjul, Gambia.

[23] Agrawal, S. (2009) Global Recession Takes toll on Kenyan Economy. Commonwealth Secretariat Marlborough House, Pall Mall, London.

[24] Bevan, J. (2007) Between a Rock and Hard Place: Armed Violence in African Pastoral Communities. United Nations Development Programme, $\mathbb{N e w}$ York.

[25] Young, H. (2006) Livelihoods, Migration and Remittance Flows in Times of Crisis and Conflict: Case Studies for Darfur, Sudan. Humanitarian Policy Group Background Research Paper. Overseas Development Institute, London.

[26] KNCHR (2014) Are We under Siege? The State of Security in Kenya. An Occasional Report (2010-2014).

[27] Masaka, O., Ratemo, D. and Ongaga, E. (2017) Effects of Interethnic Conflicts on Rural People's Livelihoods in Kenya-Case of Kenyenya and Rongo Sub-Counties in the Lake Victoria Basin. Arts Social Science Journal, 8, 253.

[28] Biko, S. (2012) Increasing Unemployment Rate Continues to Push Kenya to the Precipice of Chaos in an Election Year. Jomo Kenyatta Printers, Nairobi.

[29] Oyugi, W.O. (2000) Politicized Ethnic Conflict in Kenya: A Periodic Phenomenon. African Conflicts: Their Management, Resolution, and Post-Conflict Reconstruction. DPMF/OSSREA, Addis Ababa.

[30] Mukinda, F. (2017) Police Map Out Election Violence Hotspots Countrywide, in Daily Nation. Nairobi.

[31] Schilling, J., Opiyo, F.E. and Scheffran, J. (2012) Raiding Pastoral Livelihoods: Mo- 
tives and Effects of Violent Conflict in North-Western Kenya. Pastoralism: Research, Policy and Practice, 2, Article No. 25.

https://doi.org/10.1186/2041-7136-2-25

[32] Kaprom, T.P. (2013) Effects of Cattle Rustling on Economic Development, a Case of Masol Location, West Pokot County. Masters of Arts Dissertation, University of Nairobi, Nairobi.

http://erepository.uonbi.ac.ke/handle/11295/55798

[33] Clark, P. (2012) The Legacy of Rwanda's Gacaca Courts. Think Africa Press, London.

[34] Peters, P.E. (2009) Challenges in Land Tenure and Land Reform in Africa: Anthropological Contributions. World Development, 37, 1317-1325.

https://doi.org/10.1016/j.worlddev.2008.08.021 